\title{
Triniti daripada Perspektif Taoisme: Analisis Pemikiran Jung Young Lee
}

\author{
Trinity from Taoism Perspective: An Analysis of Jung Young Lee's Thought
}

\author{
ZURAIZA HUSIN* \& JAFFARY AWANG ${ }^{1}$
}

\begin{abstract}
Jung Young Lee is a Korean-born theologian who employs creatively the doctrine of the Trinity from an Asian worldview. This article aims to analyze Lee's approaches of the Trinity with the Yin-Yang symbolism. The main reference is based on the book written by him entitled 'The Trinity in Asian Perspective (1996)'. Lee has turned his attention to the topic of Trinity through the lens of the culture and thought patterns of his own milieu. One of the leading point in presenting Yin-Yang principle as Trinitarian thinking, Lee examines the interpretation of the term "in" in the Bible, "Believe me that I am in the Father and the Father is in me" Uohn 14:11). The statement leads to the point that Yin and Yang cannot exist without each other because relationality is given priority than individuality. The idea is based on the terminology of 'both/and'. So, 'and' indicates a Trinitarian statement, there is interdependence and unification. With reference to Trinity, the Father and the Son are One because of 'and'. In addition, the same concept implements to the Holy Spirit. Lee views 'and' is not only a linking principle in both-and thinking but also the principle that is 'between' two. When 'two' exists, the third also exist between them. Based on the idea of 'middle', represents the connecting element between two, which contributes for the existence of the Third. Accordingly, the Spirit is the third element in the Trinity relationship.
\end{abstract}

Keywords: Christianity, Jung Young Lee, Taoism, Trinity, Ying \& Yang

Jung Young Lee dilahirkan pada tahun 1935 Masihi di Korea Utara dan merupakan penganut Kristian aliran Protestant (United Methodist). Beliau berhijrah ke Amerika Syarikat dalam usia yang masih muda dan mendapat pendidikan di sana. Lee telah mendalami teologi Barat dengan memberi tumpuan kepada penulisan ahli-ahli teologi Euro-Amerika. Kemudiannya, beliau mula berjinak mendalami teologi dan budaya Asia sehingga menjadi ahli teologi Asia yang menggabung jalin kedua-dua teologi dalam idea dan penulisannya (Kärkkäinen 2007).

Dalam membincangkan falsafah Asia Timur, Lee menggunakan istilah 'kosmosantropologi' untuk menyatakan hubungan antara manusia dan alam semesta. Hubungan ini tidak dapat dipisahkan kerana kosmologi adalah asas untuk memahami sifat manusia. Menurut andaian kosmos-antropologi, proses pemikiran kita adalah tertakluk kepada putaran alam. Sebagai contoh, sekiranya kosmos (alam semesta) beroperasi melalui konsep Yin dan Yang, maka aktiviti manusia juga mematuhi prinsip yang sama. Oleh itu, Yin dan Yang adalah simbol utama dalam falsafah pemikiran Asia Timur (Lee 1996).

\footnotetext{
1 Zuraiza Husin*(Corresponding author), Ph.D. candidate at Department of Theology and Philosophy, Faculty of Islamic Studies, Universiti Kebangsaan Malaysia, 43600 BANGI Selangor, Malaysia; Jaffary Awang, Ph.D., associate professor at Department of Theology \& Philosophy, Universiti Kebangsaan Malaysia, 43600 BANGI Selangor, Malaysia, e-mail: jaffary@ukm.edu.my.
} 
Berdasarkan pemikiran fahaman Tao mengenai kosmos, pada mulanya alam adalah lompang yang disebut sebagai $W u$ Chi. Semua yang ada di dunia terdiri daripada dua entiti atau kekuatan yang berlawanan. Daripada $W u C h i$ kemudian terbit tenaga negatif disebut Yin dan tenaga positif dikenali sebagai Yang. Interaksi antara dua tenaga ini melahirkan Tai Chi. Yin mewakili alam bumi iaitu alam fizikal dan material manakala Yang mewakili alam langit atau alam spiritual. Tai Chi adalah hasil pertautan antara Yin dan Yang, ia dianggap sebagai manifesto Tao.

Tai Chi digambarkan dengan sebuah bulatan yang dibentuk oleh dua tenaga (force) iaitu Yin dan Yang. Bahagian yang gelap bertitik putih (O) mewakili Yin dan bahagian yang terang bertitik hitam $(\bullet)$ mewakili Yang. Dengan 'mata' masing-masing yang berlawanan dengan keadaan tubuhnya, maka kedua-duanya menjadi neutral. Oleh itu, peranan Yin dan Yang adalah untuk memastikan kedua-duanya seimbang dan harmoni. Yin adalah negatif, pasif dan terdedah kepada kemusnahan manakala Yang pula ialah tenaga positif, aktif dan konstruktif. Yin dianggap wanita dan Yang berwatak lelaki. Maka daripadanya terbina teori berpasangpasangan (Ghazali 2013).

\section{Ciri-Ciri Asas Yin dan Yang}

Lee menghuraikan prinsip Yin dan Yang dengan berpandukan kepada I Ching (Kitab Perubahan) yang merupakan buku kosmologi paling awal di China dan Asia Timur. Menurut Kitab Perubahan, 'perubahan' dianggap sebagai mutlak dan setanding dengan 'Tao' atau Kebenaran Mutlak (Great Ultimate) (Lee, 1996). Menurut Ghazali (2013), 'Tao' ialah jalan menuju Kebenaran, maka daripada 'Tao' terpancarlah alam semesta dan segala yang ada. Konsep ini menganggap Tuhan berada pada segala yang ada iaitu makhluk. Yin dan Yang dinyatakan dengan lebih jelas di lampiran Kitab Perubahan iaitu, "Ada yang mutlak yang menghasilkan dua bentuk, Yin dan Yang dan daripada kedua-duanya menghasilkan semua perkara ... Yin dan Yang merupakan apa yang dipanggil Tao" (Lee 1996: 24).

Di dalam Kitab Perubahan (I Ching), ideogram ' $I$ ' terdiri daripada matahari dan bulan iaitu Yang dan Yin. Ini seolah-olah menunjukkan bahawa prinsip asas yang mengatur alam semesta ini adalah pergerakan matahari dan bulan atau hari dan malam. Maksud literal bagi Yang ialah bahagian yang terang di bukit, manakala Yin adalah bahagian yang redup di bukit. Yang melambangkan matahari, selatan, cahaya, siang, kebakaran, merah, kering, panas, musim bunga, musim panas dan lain-lain. Manakala Yin menandakan bulan, utara, gelap, malam, air, hitam, sejuk, kelembapan, musim luruh, musim sejuk dan sebagainya. Yang adalah langit manakala Yin ialah bumi. Yang bergerak ke atas dan Yin bergerak ke bawah. Yang adalah bersifat maskulin manakala Yin adalah bersifat feminin. Yang positif, Yin negatif. Yang ialah aktiviti dan Yin adalah ketenangan. Yang adalah gerak dan Yin ialah istirehat. Yang adalah kehidupan tetapi Yin ialah kematian. Segala sesuatu di dunia boleh dikategorikan kepada Yin dan Yang. Oleh yang demikian, Yin dan Yang adalah prinsip-prinsip kosmik yang mewakili segala sesuatu (Lee 1979).

Walaupun Yin dan Yang adalah berlawanan dalam ciri-cirinya, mereka adalah bersatu. Untuk memahami hubungan antara Yin dan Yang dengan melihat gambar garisan di dalam Kitab Perubahan. Didapati Yin dinyatakan dengan garisan putus-putus (- - ), manakala Yang dikenali dengan garisan tidak putus $(-)$. Pada asalnya, Yin mewakili titik gelap $(\bullet)$ iaitu simbol bulan, manakala Yang titik terang $(\circ)$ mewakili simbol matahari. Adalah dipercayai bahawa titik gelap dan terang kemudian digantikan dengan garisan putus-putus dan tidak putus untuk memberi penjelasan yang lebih mudah di dalam Kitab Perubahan. Dinyatakan bahawa garisan putusputus adalah merupakan sebahagian daripada garisan tidak putus. Manakala garisan tidak putus adalah gabungan daripada garisan putus-putus. Ini menunjukkan garisan-garisan ini adalah sama cuma yang membezakan mereka ialah aspek pembahagian dan penyatuan. Ini 
menunjukkan ia bukan satu inti pati (substance) tetapi berupa suatu aktiviti atau perubahan dinamik (dynamic of change) yang menjadikan Yin dan Yang adalah berbeza (Lee 1996).

Justeru itu, apa yang menjadi keutamaan kepada hubungan Yin-Yang bukannya entiti tetapi perubahannya. Berdasarkan Kitab Perubahan, ' $I$ ' atau perubahan adalah realiti atau kebenaran mutlak. Oleh itu, Yin dan Yang adalah simbol-simbol utama kepada 'pergerakan atau tindakan' bukannya simbol entiti atau inti pati. Di samping itu juga, Yin dan Yang adalah relatif kerana mereka merupakan 'simbol hubungan'. Mereka adalah perubahan yang menghasilkan entiti sendiri. Oleh yang demikian, Yin dan Yang pada dasarnya adalah tenaga aktif yang membentuk perubahan. Dalam aktiviti-aktiviti perubahan, hubungan lebih diutamakan daripada entiti atau inti pati (Lee 1996).

Buku Perubahan juga menyatakan corak perubahan di dalam Yin dan Yang adalah seperti berikut, "Apabila matahari terbenam, bulan muncul. Ketika bulan terbenam, matahari terbit ... " (Lee 1996: 29). Ini bermakna bahawa apabila sesuatu itu mencapai tahap maksimum, ia akan merosot. Begitu juga apabila ia telah mencapai tahap minimum, ia akan mengembang. Sebagai contoh, apabila cahaya matahari mencapai tahap maksimum pada tengah hari, kegelapan akan muncul sebagai tahap minimum dan begitu juga sebaliknya. Dapat difahami daripada situasi ini, apabila Yin mengembang maka Yang akan merosot dan ia akan berlaku secara selang seli.

Oleh itu, proses 'mengembang dan merosot' secara selang seli dalam hubungan Yin-Yang menunjukkan aktiviti yang bertentangan tetapi mempunyai batasan tersendiri. Yin tidak boleh mengembang selama-lamanya, sebagaimana Yang juga tidak boleh berbuat demikian. Yin adalah terhad kerana Yang dan juga sebaliknya. Dalam erti kata lain, sesuatu itu dibatasi oleh yang berlawanan dengannya dan ini bermakna Yin dan Yang tidak boleh menjadi mutlak dengan sendirinya. Ia mempunyai kaitan antara satu sama lain. Yin tidak boleh wujud dengan sendirinya kerana kewujudannya ada kaitan dengan Yang dan sebaliknya. Jadi, Yin dan Yang bukan sahaja berkait antara satu sama lain tetapi berkait secara 'menyeluruh'. Konsep ini dikenali sebagai Tai Chi dan ' $I$ ' atau perubahan dibentuk oleh kekuatan atau tenaga daripada Yin dan Yang (Lee 1996).

Di samping itu juga, Ying-Yang adalah simbol dualisme yang tidak bercanggah tetapi saling melengkapi. Dalam dualisme percanggahan, mereka harus berjuang dengan lawan untuk mencapai kemenangan dengan cara menghapuskan pihak lawan. Walau bagaimanapun, dalam 'dualisme pelengkap' (complementary dualism), mereka tidak perlu berlawan tetapi saling melengkapi kerana pada dasarnya yang bertentangan itu adalah sebahagian daripada diri mereka sendiri. Sebagai contoh, lelaki dan perempuan adalah bertentangan tetapi saling melengkapi dalam hubungan perkahwinan. Oleh itu, Yin dan Yang merupakan simbol rangkuman (inclusive) dan menyeluruh serta simbol kesempurnaan atau keutuhan yang membawa kepada keharmonian (Lee 1996).

\section{Pemikiran Triniti Ying dan Yang}

Lee menggarap idea dengan mengemukakan prinsip Yin dan Yang sebagai pemikiran Triniti. Jika kita mengamati simbol Yin dan Yang, didapati bahawa Yin mempunyai titik Yang (O) di dalamnya dan Yang mempunyai titik Yin $(\bullet)$ di dalamnya. Titik-titik ini melambangkan 'dalam (in)' yang menjadi prinsip penghubung dan juga boleh dikaitkan dengan Triniti. Dalam memahami prinsip Yin dan Yang, Lee (1996) meneliti tafsiran istilah 'dalam (in)' di dalam Bible (Yohanes 14:11):

Percayalah kepada-Ku, bahawa aku di dalam Bapa dan Bapa di dalam Aku. 
Ini bermakna apabila Yin dan Yang termasuk dan dimasukkan ke dalam satu sama lain, mereka mewujudkan hubungan Triniti. Apabila Yin dan Yang merupakan simbol hubungan, Yin tidak boleh wujud tanpa Yang dan sebaliknya. Tambahan pula, Yin dan Yang adalah berkaitan antara kedua-duanya kerana mereka dimasukkan ke dalam satu sama lain. Rangkuman ini hanya boleh dilambangkan oleh kata depan 'dalam (in)' yang menjadi prinsip hubungan dalaman Yin dan Yang. Oleh itu, Tuhan Bapa dan Tuhan Anak adalah Satu berdasarkan istilah 'dalam (in)' ini.

Lee juga menyatakan cara terbaik untuk menjelaskan ciri-ciri Yin dan Yang adalah menggunakan terminologi 'kedua-dua/dan (both/and)'. Ia melibatkan konsep hubungan dan rangkuman. Ia tidak dapat dikategorikan dalam istilah 'sama ada/atau(either/or)' kerana prinsip ini akan membawa kepada dualisme percanggahan yang perlu kepada pilihan dan penyisihan. Contohnya, perlu membuat pilihan antara baik atau buruk, betul atau salah. Oleh itu, Yin dan Yang sentiasa wujud bersama dengan yang berlawanan tetapi pada masa yang sama menjadi pelengkap antara satu sama lain (Lee 1996). Kenyataan lain di dalam Bible yang dapat dikaitkan dengan Yin dan Yang adalah seperti: "Bapa dan saya adalah Satu" (Yohanes 10:30).

Tafsiran membawa kepada maksud bahawa Yin dan Yang tidak boleh wujud tanpa satu sama lain kerana konsep hubungan lebih menjadi keutamaan berbanding individualiti. Ini kerana prinsip tersebut adalah berdasarkan kepada 'kedua-dua/dan (both/and)' dan bukannya 'sama ada/atau (either/or)'. Justeru itu, 'dan (and)' menandakan satu kenyataan Triniti yang menunjukkan saling bergantungan dan penyatuan. Berhubung dengan Triniti, kedua-dua Tuhan Bapa dan Tuhan Anak adalah Satu kerana prinsip 'dan (and)'.

Di samping itu, persoalan timbul bagaimana pula prinsip Yin dan Yang dapat dikaitkan dengan Roh Kudus? Lee memberi penyelesaian dengan merujuk kepada prinsip yang sama iaitu terminologi 'kedua-dua/dan (both/and)'. Beliau berpandangan, 'dan (and)' bukan hanya satu prinsip yang menghubungkan antara kedua-duanya tetapi juga prinsip 'antara (between)' yang wujud antara kedua-duanya. Apabila 'dua' wujud, yang ketiga akan wujud antara mereka. Berdasarkan pemikiran ini, 'tengah (middle)' mewakili elemen penghubung antara keduaduanya dengan wujudnya Yang Ketiga (Lee 1996).

Sehubungan dengan itu, Lee meringkaskan hubungan antara pemikiran simbolik Yin dan Yang dengan pemikiran Triniti Kristian seperti berikut, apabila ada Kedua-dua akan ada Tiga kerana Yang Ketiga adalah Pengantara. Yin adalah Yang kerana ia termasuk dalam Yang, seperti mana Yang termasuk dalam Yin. Oleh itu, kedua-duanya Yin dan Yang adalah Satu dan Satu adalah Dua. Mereka juga Tiga kerana mengandungi "Pengantara" yang menghubungkan mereka. Justeru, dalam pemikiran simbolik Yin dan Yang, Satu dalam Tiga dan Tiga dalam Satu adalah kerana Dua. Tanpa Dua, pemikiran Triniti tidak mungkin berlaku kerana memahami konsep dua (two-ness) adalah penting untuk memahami hubungan antara Satu dan Tiga (Lee 1996 \& Kärkkäinen 2007).

Idea Triniti ini dikaitkan dengan alam semula jadi yang melibatkan langit, bumi dan manusia/makhluk. Konsep ini diperkenalkan oleh Chang Tsai (1021-1077 Masihi) yang merupakan sarjana Neo-Kongfusianisme di dalam karyanya Ming Hsi. Menurutnya langit (ch'ien) merupakan bapa manakala bumi (k'un) adalah ibu. Manusia merupakan makhluk yang berada di antara keduanya yang berfungsi sebagai anak dan adik beradik. Ia juga melibatkan makhluk lain sebagai penghuni alam semesta. Dengan menggunakan simbol kekeluargaan ini, ia menjadi sangat dekat dengan idea Triniti dalam Kristian iaitu Tuhan Bapa, Tuhan Anak dan Roh Kudus. Bapa berkait rapat dengan langit (syurga) dan dia dipanggil sebagai Bapa syurgawi. Manakala Roh Kudus kaitannya dengan bumi yang bersifat feminin dan mewakili simbol Ibu. Anak pula dikaitkan sebagai hasil daripada hubungan Bapa dan Ibu. Ini adalah satu paradigma yang berguna dalam menjelaskan Triniti daripada perspektif Asia Timur (Lee 1996).

Lee mengupas Triniti dengan memberi idea baru dalam turutan kedudukan ahli Triniti. Beliau memulakan perbincangan dengan Tuhan Anak dan bukannya Tuhan Bapa sebagaimana Kristian tradisional. Bagi beliau, Tuhan Bapa dikenali melalui Tuhan Anak. Kewujudan Tuhan 
Anak dalam 'dua bentuk' iaitu sebagai manusia dan tuhan bersesuaian dengan prinsip Yin dan Yang. Melalui perkembangan prinsip dua akan membawa kepada kefahaman tentang tiga iaitu Triniti.

\section{Tuhan Anak}

Penjelmaan (Inkarnasi) Jesus adalah asas untuk memahami Triniti kerana ia berfungsi sebagai imej dalam menjelaskan konsep ketuhanan. Konsep penjelmaan Jesus ada kaitan dengan kosmos seperti yang dinyatakan di dalam Bible (Yohanes 1:14):

Firman itu sudah menjadi manusia dan tinggal antara kita. Kita nampak kemuliaan-Nya, kemuliaan yang diterima-Nya sebagai anak tunggal Bapa. Melalui Dia, kasih Allah dan Allah sendiri ditunjukkan kepada kita.

Ini membawa maksud bahawa penjelmaan Firman atau Jesus ada kaitannya dengan proses alam semesta dan kemudian menjelma sebagai Anak. Dengan mengambil sifat manusia, Firman menjadi manusia yang merupakan satu-satunya Anak Tuhan (Lee 1996). Idea yang sama juga dapat dilihat berdasarkan ayat ini (Bible, Filipi 2: 5-9):

Sikap kamu hendaklah seperti sikap Kristus Jesus: Sebenarnya Dia Ilahi, tetapi Dia tidak menganggap keadaan-Nya yang Ilahi harus dipertahankan-Nya. Sebaliknya, Dia rela melepaskan segala-galanya, lalu menjadi seperti seorang hamba. Dia datang sebagai manusia, dan hidup seperti manusia. Dia merendahkan diri dan hidup dengan taat kepada Allah sehingga mati - iaitu mati di atas salib. Itulah sebabnya Allah meninggikan Dia setinggi-tingginya, dan mengurniai Dia kedudukan yang lebih tinggi daripada semua kedudukan yang lain.

Penjelmaan Jesus dalam bentuk manusia diibaratkan seperti proses 'pengosongan (empty)' dan 'kepadatan (fullness)'. Proses pengosongan daripada kepadatan dengan menjadi seorang hamba dan kemudian diangkat sehingga mendapat kemuliaan yang lebih tinggi. Yin dan Yang juga mempunyai konsep ini di mana proses mengosongkan dan memenuhi tidak dapat dipisahkan. Kedua-dua proses berjalan pada masa yang sama iaitu proses pengosongan daripada sifat kemuliaan sebagai tuhan kemudiannya dipenuhi dengan proses rendah diri sebagai manusia. Proses ini terjadi serentak kerana konsep 'dalam (in-ness)', yang melibatkan sifat ketuhanan dan manusia dalam penjelmaan Tuhan Anak (Lee 1996).

Lee memberi pandangan yang lebih terperinci dengan membezakan terminologi Jesus dan Christ. Bagi beliau Christ melambangkan simbol ketuhanan manakala Jesus adalah simbol kemanusiaan. Oleh itu, Tuhan Anak 'Jesus-Christ' memiliki sifat ketuhanan dan juga manusia. Di dalam Bible (Lukas 2:7) ada menyatakan:

Dia melahirkan seorang anak lelaki, anaknya yang sulung. Anak itu dibedungnya lalu diletakkan di dalam palung, kerana mereka tidak mendapat tempat untuk menumpang.

Dapat difahami daripada ayat ini bahawa kelahiran Jesus di dalam palung seolah-olah bersesuaian dengan pengosongan Jesus sebagai seorang hamba. Di dalam palung semua makhluk terutama haiwan adalah sahabat Jesus. Oleh itu, Jesus mengosongkan dirinya untuk diletakkan di dalam palung dan berada pada kedudukan yang paling rendah untuk menyatukan kedua-dua dunia manusia dan juga haiwan. Ini adalah situasi yang mengaitkan dirinya dengan alam semesta. Dalam bentuk sebagai seorang hamba dan simbol "palung" menjadikan status Jesus sangat rendah. Kehebatan Jesus-Christ terletak pada penolakan hak dan keistimewaan 
dengan mengosongkan kemuliaan dan kuasa-Nya, menjadi orang yang hina dan tidak berdaya, iaitu hamba. Dengan menjadi orang yang hina, Jesus adalah penghubung di antara dua dunia yang berbeza iaitu dunia langit dan dunia bumi, dunia Bapa dan dunia Ibu (Roh) (Lee 1996). Begitu juga dengan pendekatan berkaitan gender lelaki dan wanita dan juga sifat perseorangan dan komuniti dalam Tuhan Anak. Berdasarkan Yin-Yang, Yin adalah simbol wanita dan Yang adalah lelaki. Oleh itu lelaki tidak wujud dengan sendirinya tanpa wanita sebagaimana Yang selalu ada bersama Yin.

Dalam hal ini, Jesus adalah seorang lelaki dan juga boleh diandaikan sebagai wanita. Isu jantina ini berkait rapat dengan sifat tunggal dan jamak bagi Jesus. Melalui konsep 'keduadua/dan' dalam hubungan Yin-Yang, Jesus merupakan seorang individu dan juga komuniti. Sekiranya Jesus bukan sahaja lelaki tetapi juga perempuan, ini bermakna dia bukan sahaja tunggal tetapi jamak. Oleh itu, dia mewakili individu dan pada masa yang sama dia juga mewakili komuniti. Dia adalah satu tetapi banyak. Oleh itu, Anak juga Tuhan Triniti kerana dia adalah satu dalam tiga dan tiga dalam satu yang dilihat daripada aspek tunggal dan jamak (Lee 1996).

Lee (1996) juga membincangkan misteri kematian dan kebangkitan semula dalam Tuhan Anak. Kematian dilambangkan oleh Yin manakala kebangkitan oleh Yang. Kematian Jesus boleh difahami sebagai pengembangan Yin ke tahap maksimum yang akhirnya ia akan merosot. Pada masa ini, Yang yang berada pada tahap minimum akan mula berkembang dan ia melambangkan kuasa kebangkitan semula. Oleh itu, kematian dan kebangkitan bertemu di titik yang sama di mana Yin berada pada tahap maksimum dan Yang di tahap minimum. Apabila Yin mencapai tahap maksimum, ia mulai berkurangan dan ketika Yang mencapai tahap minimum, ia mulai berkembang. Pengembangan dan pengecutan bersama menjadikan semua perkara perlu berubah.

Mengenai hubungan antara Tuhan Anak dan Tuhan Bapa. Lee (1996) membuat kejutan dengan mendakwa bahawa berlakunya kesilapan semasa zaman awal ortodoks Kristian dalam mengemukakan prinsip homoousios iaitu (Fisher 1901: 136-137):

The generation of the Son is an internal and therefore an eternal, act of God. The Son is not 'from the non-existent', but from the essence of the Father. He is of the same substance - homoousios with the Father.

Prinsip ini menyatakan bahawa Tuhan Bapa dan Tuhan Anak adalah daripada inti pati ketuhanan yang sama. Beliau lebih cenderung merujuk kepada pandangan yang dibawa oleh Emil Brunner (1889-1966) yang didakwa wujudnya subordinat dalam ketuhanan Triniti (mempunyai kedudukan yang berbeza antara satu sama lain).

Lee mendakwa bahawa tidak terdapat ayat di dalam Perjanjian Baru menyatakan tentang identiti Anak sama dengan Bapa. Kenyataan di dalam Bible (Yohanes 10:30), "Bapa dan saya adalah Satu" tidak harus dibaca dengan maksud "Saya adalah Bapa dan Bapa adalah Saya". Bagi Lee, menyamakan Bapa dengan Anak bermakna menyamakan Pencipta dengan Penyampai Wahyu. Bapa adalah sebagai Pencipta mempunyai kuasa yang mutlak. Kedudukannya lebih tinggi berbanding Jesus kerana tugas sebagai Penyelamat dan Penebus Dosa adalah merupakan sebahagian daripada tugas Bapa sebagai Pencipta. Oleh itu, Jesus adalah subordinat kepada Bapa. Ini adalah pembetulan kepada salah tanggapan dalam teologi tradisional. Bagi Lee, konsep ini disamakan dengan hierarki dalam tradisi Kungfucius yang menetapkan ketaatan Anak kepada Bapa (Kärkkäinen 2007).

Daripada segi penderitaan tuhan dan kasih sayang; penderitaan Tuhan hanya boleh difahami melalui kasih sayang. Ia adalah kasih sayang Tuhan Bapa dengan mengutus Anak-Nya menderita di tiang salib. Penderitaan Anak tidak lain hanyalah sebagai ungkapan kasih sayang Tuhan. Kasih sayang Tuhan diserlahkan melalui Jesus. Apabila kewujudan Tuhan ditolak maka kasih sayang akan terasing. Kerenggangan dalam hubungan kasih sayang membawa kepada 
penderitaan Tuhan. Oleh itu, kasih sayang dan penderitaan tidak dapat dipisahkan dan sentiasa bersama-sama (Lee 1996).

\section{Roh Kudus}

Roh dalam Triniti dapat difahami melalui terminologi ruach dalam bahasa Ibrani dan pneuma dalam bahasa Yunani. Ia membawa maksud 'angin' dan 'nafas'. Manakala di dalam kesusasteraan Veda yang lebih tua bermaksud 'nafas kehidupan'. Daripada perspektif Asia Timur pula, Roh Kudus ialah $c h ' i$. Ch'i diberi definisi sebagai tenaga yang penting untuk menggerakkan kuasa dan merupakan inti pati kepada semua kehidupan (Kärkkäinen 2007).

Sekiranya ruarch (bahasa Ibrani) dan pneuma (bahasa Yunani) diterjemahkan sebagai Roh di dalam Perjanjian Lama dan Perjanjian Baru, maka Roh adalah "angin" di alam semula jadi dan "nafas" kepada kehidupan. Dengan kata lain, angin melambangkan kuasa hidup dalam alam semula jadi, sementara nafas melambangkan kuasa hidup dalam kehidupan. Angin dan nafas kedua-duanya adalah kuasa, kerana mereka mewakili pergerakan Yin dan Yang. Pergerakan Yin-Yang adalah $c h ' i$ kerana $c h ' i$ merangkumi aktiviti Yin dan Yang. Ini disebabkan Yin dan Yang bersifat sentiasa ada, maka Roh sebagai angin dan nafas juga sentiasa hadir di setiap masa dan tempat. Berdasarkan prinsip $c h^{\prime} i$, tiada perbezaan yang ketara antara angin dan nafas kerana $c h ' i$ adalah inti pati kepada semua kehidupan dan kewujudan, termasuk yang hidup dan tidak hidup (Lee 1996).

Justeru itu, pada pandangan Lee Roh Kudus sebagai angin mewakili sifat ketuhanan yang tidak bersifat insani. Manakala Roh Kudus sebagai nafas kepada makhluk ciptaan-Nya berupa sifat yang insani. Di samping itu, Roh Kudus mewakili simbol Yin dan juga bersifat bersedia menerima, tanpa nama, ketenangan dan kewanitaan. Simbol ch'i adalah berkaitan dengan feminin (Ibu) dan juga Bumi. Beberapa imej dan metafora boleh digunakan daripada semangat feminin, pelindung dan pemelihara bumi, seperti menenun pakaian, air, sebuah pengangkutan yang menggerakkan komuniti dan lain-lain (Kärkkäinen 2007).

\section{Tuhan Bapa}

Dalam ketuhanan Triniti, Lee menyatakan Tuhan Bapa mempunyai kedudukan yang paling unggul berbanding Tuhan Anak dan Roh Kudus. Ini kerana dengan sifat semula jadi sebagai Bapa, Dia adalah lebih dominan dibandingkan dengan Anak. Daripada segi hubungan Bapa dengan Roh Kudus (Ibu), Lee mengaitkannya dengan hierarki kekeluargaan di Asia Timur yang mana lelaki (suami) adalah lebih berkuasa daripada wanita (isteri). Bahkan dalam hubungan Yin-Yang, Yang sentiasa berada di hadapan Yin. Sebagai contoh di dalam Kitab Perubahan, dimulakan dengan Yang (Ch'ien) dan seterusnya Yin (K'un). Oleh itu, Yang lebih menonjol berbanding Yin (Lee 1996).

Adapun Tuhan Bapa digambarkan sebagai li. Li mewakili prinsip syurgawi dan juga sebagai prinsip rohani dan moral. Gagasan $c^{\prime} i$ (Roh Kudus) dan li telah dibangunkan sepenuhnya oleh Chu Hsi (1130-1200 Masihi), yang merupakan seorang sarjana besar dalam pembinaan teori kewujudan dan meletakkan dirinya ke taraf Neo-Kungfusianisme ortodoks. Beliau menegaskan bahawa li tidak terpisah dari $c h$ 'i kerana kedua-duanya adalah inti pati kepada segala sesuatu (essence of all things). Walau bagaimanapun, sekiranya beliau diminta untuk memberikan keutamaan antara li dan $c^{\prime} h i$, beliau memilih li berbanding $c^{\prime} h i$, walaupun pada hakikatnya ia tidak mungkin berlaku. Di sini, dapat diterapkan idea Chu Hsi dengan memberi kemuliaan yang lebih utama kepada Bapa (li) berbanding Roh Kudus (c'hi). Sebagaimana li dan $c^{\prime} h i$ tidak boleh dipisahkan begitu juga Tuhan Bapa dengan Roh Kudus (Lee 1996). Bapa adalah bersifat maskulin sementara Roh Kudus bersifat feminin (Ibu). Sifat kelelakian melengkapkan sifat kewanitaan begitu juga dengan Bapa sebagai simbol langit/syurga melengkapkan bumi sebagai simbol wanita (Ibu). 
Di samping itu juga, bapa yang mewakili Syurga/Langit mempunyai prinsip moral dan kerohanian yang tinggi seperti originator (yang memulakan), kejayaan, keadilan (keuntungan) dan kebenaran. Originasi dalam perkataan Cina ialah yuan, secara literal bererti kepala, besar dan mulia. Idea yuan membantu kita untuk memahami bahawa Bapa adalah pencetus kasih sayang (jen), yang diterbitkan oleh Roh Kudus dan diwujudkan dalam penjelmaan Anak. Manakala Bapa adalah kejayaan, perkataan Cina bagi kejayaan ialah heng yang bermaksud menembusi atau menyerap. Kejayaan pada dasarnya bererti menyerapkan rasa kasih sayang dan cinta kepada seluruh umat manusia. Ia mewujudkan suasana harmoni dengan menembusi setiap sudut dunia.

Sifat yang ketiga ialah Bapa adalah kelebihan, yang dikenali melalui perkataan China $i$ membawa maksud kebenaran atau keadilan. Keadilan adalah kualiti moral yang dikurniakan dalam diri seseorang sesuai dengan sifat semula jadinya yang membuat hidup orang lain bahagia dan bermakna. Bapa adalah kebenaran. Perkataan Cina untuk kebenaran adalah cheng, ertinya kebenaran ketuhanan dan jawapan yang betul. Ini adalah pengetahuan yang tepat lagi bijaksana bagi sifat ketuhanan. Semua sifat-sifat Bapa ini adalah saling berkaitan antara satu sama lain (Lee 1996).

Di antara karakter Bapa, kreativiti juga mempunyai fungsi yang penting. Kreativiti ialah imej bagi Pencipta kerana Syurga atau Kreativiti di dalam Kitab Perubahan penuh dengan kekuasaan dan dilambangkan oleh seekor naga. Di negara Cina, naga sebagai simbol maharaja kerana kuasa yang luar biasa. Walau bagaimanapun, orang-orang Barat menganggap naga bermakna jahat seperti di dalam Bible - Kitab Wahyu 12:7-17 yang membawa maksud Tuhan adalah berperang dengan naga itu, yang mewakili syaitan. Dalam proses kreativiti, hubungan antara Pencipta dan makhluk adalah melalui pengantaraan Anak. Berperanan sebagai Anak, Pencipta akan menjadi makhluk, walau bagaimanapun Pencipta tidak kehilangan identitinya dan begitu juga sebaliknya. Oleh itu, dalam proses kreativiti kedua-duanya iaitu syurga (Pencipta) dan bumi (makhluk) adalah bersatu. Maka dalam proses kreativiti, Pencipta bertindak sebagai prinsip penyatuan dalam Triniti (Lee 1996).

Sehubungan dengan itu, bapa sebagai prinsip yang menyatukan kehidupan keluarga adalah seperti satu pusat yang menarik seluruh ahli keluarga bersama-sama hidup dalam suasana harmoni. Walau bagaimanapun, dalam proses perubahan yang dinamik dan transformasi hubungan, kedudukan pusatan (center) tidak pernah tetap. Pusatan ini sentiasa dipengaruhi oleh tepi atau margin kerana margin yang kreatif akan bertukar menjadi pusatan, seperti mana pusatan beralih dan menjadi margin. Sebagaimana prinsip Yin dan Yang, setiap sesuatu adalah berubah dan mentransformasikan dirinya. Contohnya, apabila Yang iaitu garisan padat (-) dibahagikan, ia akan berubah kepada Yin iaitu garisan putus-putus (- -). Di sini, kita melihat bahawa garisan padat dibahagikan dan menjadi dua barisan yang akan membesar dan membahagikan diri mereka kepada empat garisan putus-putus (- - - ). Oleh itu, proses perubahan dan transformasi ini akan berterusan dan tiada penghujung. Jadi, dalam pemikiran Triniti, Tuhan Bapa adalah pusatan utama yang mana boleh dimarginal oleh Roh Kudus dan juga Tuhan Anak. Adakalanya Tuhan Anak boleh menjadi pusatan dan begitu juga dengan Roh Kudus. Proses pemusatan dan peminggiran adalah prinsip yang sangat dinamik dalam penyatuan ketuhanan Triniti ini.

\section{Perbincangan}

Triniti merujuk kepada kefahaman orang Kristian tentang Tuhan sebagai penyatuan tiga entiti iaitu; Tuhan Bapa (Father), Tuhan Anak (Son of God) dan Roh Kudus (Holy Spirit). Ketiga-tiganya adalah Tuhan dan ia adalah ia (tuhan yang sama) yang setiap satu berkongsi sifat-sifat ketuhanan yang muktamad, abadi (kekal) dan tidak berubah (Grolier Encyclopedia of Knowledge, 1993). Ini adalah definisi Triniti yang menjadi asas pegangan orang Kristian. Adapun perspektif Triniti berdasarkan prinsip Yin dan Yang menghadapi cabaran yang besar dan kritikal kerana pendekatannya begitu berbeza daripada Triniti tradisional. 
Simbol Yin dan Yang, yang diketengahkan oleh Lee untuk menjelaskan Triniti boleh membawa kepada konsep Modalism. Konsep ini memahami bahawa Tuhan Bapa, Tuhan Anak dan Roh Kudus adalah Tuhan yang Satu tetapi wujud dalam tiga entiti/mod ketuhanan yang mempunyai fungsi dan peranan yang berbeza, contohnya Tuhan Bapa adalah Pencipta, Tuhan Anak merupakan Penebus Dosa manakala Roh Kudus adalah Pemberi Rahmat dan Kasih Sayang (Coppedge 2007). Sebagai contoh, Lee tidak dapat lari daripada konsep ini apabila menjelaskan tentang Bapa (sebagai Perubahan) adalah seperti Tao dan adakalanya menyatakan Anak adalah seperti Tao (Lee, 1996). Ini menggambarkan Lee melabelkan Tuhan dengan fungsi tertentu dan berbeza.

Di samping itu, Lee menganggap penggunaan terminologi homoousios dalam Triniti tradisional adalah tidak tepat. Homoousios dalam bahasa Yunani digunakan untuk menyatakan penyatuan Tuhan yang membawa maksud bahawa Anak berkongsi inti pati 'ketuhanan' yang sama dengan Bapa (Coppedge 2007). Sebagaimana yang dinyatakan di dalam Nicaea Creed (325 Masihi), Anak adalah "dilahirkan dan tidak dijadikan" (begotten not made), juga dinyatakan bahawa Anak berkongsi intipati yang sama (homoousios) dengan Bapa. Ini meyakinkan bahawa Anak berkongsi intipati 'ketuhanan' (divine) yang sama dengan Bapa. (Letham, 2004; Coppedge, 2007 \& Night, 2008). Cara Lee menyokong pandangannya tidak begitu meyakinkan kerana beliau mempersoalkan interpretasi kenyataan di dalam Bible iaitu "Bapa dan saya adalah Satu" Yohanes 10:30, yang berkaitan dengan penyatuan antara Tuhan Bapa dan Tuhan Anak. Bagi Lee, Bapa dan Anak tidak sama kerana Bapa sebagai Pencipta mempunyai kuasa yang mutlak berbanding Jesus. Oleh itu, Anak menjadi subordinat (berada di kedudukan lebih bawah) kepada Bapa. Walau bagaimanapun Lee tidak mengemukakan alternatif kepada terminologi homoousios. Isu subordinat boleh diperjelaskan lagi dengan melihat pandangan Lee yang merujuk kepada Buku Perubahan, "Yang adalah lebih menonjol berbanding Yin" (Lee 1996:129). Oleh itu, penekanan Lee dengan menyatakan Yin dan Yang merupakan simbol rangkuman (inclusive) dan menyeluruh seolah-olah boleh diragui kerana wujudnya tingkatan yang berbeza antara Yin dan Yang.

Lee juga memulakan perbincangan mengenai Triniti dengan isu Tuhan Anak, Roh Kudus dan Tuhan Bapa. Ini bertentangan dengan Triniti tradisional yang meletakkan susunan Triniti yang dimulai dengan Tuhan Bapa, Tuhan Anak dan Roh Kudus. Sebagaimana pandangan yang dikemukakan oleh Cappadocia Fathers. Mereka terdiri daripada Basil (329-379 Masihi) yang merupakan paderi di Caesarea, Gregory dari Nyssa (lahir antara 335 dan 341 Masihi) paderi di Nyssa dan Gregory dari Nazianzus (325-389 Masihi) (McGrath, 2011 \& Khaled, 2011). Dalam menganalisis kedudukan tiga entiti dalam triniti, walaupun berbeza dengan apa yang difahami oleh pihak Kristian, namun Lee sendiri tidak menyatakan secara jelas alasan kenapa kronologi yang dikemukakan oleh beliau sebagai rasional. Jika tidak kronologi ini tidak lebih sebagai satu susunan tanpa apa-apa justifikasi dari sudut teologi mahupun rasional.

Walaupun penulis-penulis Cappadocia tidak menerima sama ada Anak atau Roh Kudus adalah subordinat kepada Bapa, namun mereka menyatakan secara jelas bahawa Bapa dianggap sebagai sumber kepada kewujudan Anak dan Roh Kudus. Anak adalah daripada Bapa dilahirkan secara semula jadi dan tidak dicipta (begotten). Roh Kudus juga adalah berpunca (proceeds) daripada Bapa. Oleh itu, Bapa adalah sebagai sumber kepada Anak dan Roh Kudus yang mana kedua-duanya wujud secara abadi disebabkan oleh Bapa.

Manakala berhubung dengan isu jantina, Lee menamakan Yang sebagai Bapa dan Yin sebagai Ibu (Roh Kudus). Idea ini pastinya ditolak oleh ahli teologi feminis kerana Lee memberi gambaran bahawa sifat kelelakian adalah kuat manakala wanita adalah lemah. Pendekatan Lee di sini tidak lebih sekadar meletakkan istilah dalam Toa bersama dengan istilah dalam Triniti. Ini kerana beliau tidak menjelaskan kewajaran istilah tersebit disamakan. Apakah sekadar kedudukan tiga entiti Triniti dan Toa, maka ia wajar disamakan. 
Sebagai kesimpulan, perbincangan di atas menunjukkan perspektif Asia Timur yang terdapat dalam konteks pemikiran Lee ternyata mempunyai ruang lingkup yang berbeza. Ia dilihat seolah-olah bertentangan dengan konsep asal Triniti. Ini kerana pengaruh agama dan budaya setempat telah mencorak Triniti dalam domain yang berbeza. Ini menggambarkan kewujudan usaha untuk memberi interpretasi berbeza dengan menggunakan konsep Tao sebagai satu bentuk pencernaan wacana baru terhadap triniti.

\section{References}

Coppedge, A. 2007. The God Who is Triune. Illinois USA: Inter Varsity Press.

Grolier Encyclopedia of Knowledge. 1993. Connecticut: Grolier Incorporated Danbury.

Fisher, G. P. 1901. History of Christian Doctrine. New York: Charles Scribner's Sons.

Ghazali Basri. 2013. Ilmu Perbandingan Agama - Satu Pengenalan. Selangor: Akademi Kajian Ketamadunan Kolej Dar al-Hikmah.

Kamus Dewan. 2010. Ed. ke-4. Kuala Lumpur: Dewan Bahasa dan Pustaka.

Kärkkäinen, V. M. 2007. The Trinity Global Perspectives. London: Westminster John Knox Press.

Khalid Anatolios. 2011. Retrieving Nicaea: The Devolepment and meaning of Trinitarian Doctrine. United States of America: Baker Academic:

Al-Kitab Berita Baik. 2001. Selangor: The Bible Society of Malaysia.

Lee, Jung Young. 1979. The Theology of Change. New York: Orbis Books.

Lee, Jung Young. 1996. The Trinity in Asian Perspective. Nashville: Abington Press.

Letham, R. 2004. The Holy Trinity - In Scripture, History, Theology and Worship. New Jersey: P\&R Publishing.

McGrath, A. E. 2011. Christian Theology: An Introduction. (5th ed.). United Kingdom: Wiley Blackwell- A John Wiley \& Sons, Ltd.

Night, K. 2008. New Advent. Retrieved from http://www.newadvent.org/. 